\title{
An Apple of Eye Legacy to the Humanity from Istanbul Medical Faculty: Professor Dr. Cemil Taşçıŏlu
}

D Gülistan Bahat

Istanbul University, Istanbul Medical Faculty, Department of Internal Medicine, Division of Geriatrics, Istanbul, Turkey

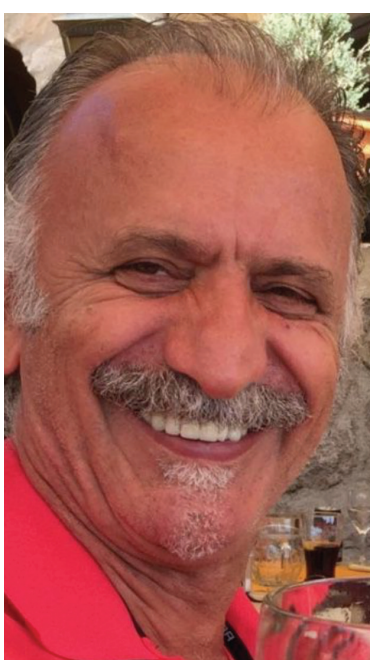

Born in Turkey, Rize in 1952, he has settled in Istanbul, Çengelköy in 1954 with his family. This is where he cultivated a personality since adolescence full of love, liberty and selfreliance, perhaps inspired by the Bosphorus. Graduating from Istanbul University, Istanbul Medical Faculty in 1977, he has completed his specialty education in internal diseases under the roof of the same institution. In 1982, after being entitled a specialist in internal diseases, he was conscripted and fulfilled his duty in Kars/Sarıkamış. Although he was appointed to Şanlıurfa as part of the "obligatory service," he "voluntarily" extended his practice there until 1989. His career advance continued with chief assistantship in Istanbul Medical Faculty, Department of Internal Medicine, General Internal Medicine in 1989; associate professorship in 1993; professorship in 1998. Though retired in 2019 due to age limit, he did not interrupt his prolific career and was employed as an adjunct professor in his home institution.

I am so lucky and have the great honor that I met him in Istanbul Medical Faculty on 1999, at the time that I have begun my residency in internal medicine. The first thing I remember with him was his generous help, emphasizing the ethical and deontological respect to his colleague. I have continued as an academician in this university in the division of geriatrics. It is our privilege and exclusive feature that the geriatrics has taken root from the division of general internal medicine in this faculty so that a geriatrician has all the skills to manage the complex needs of the older adults, not focusing on an organ but on the whole picture of the patient. We worked and studied with him hand to hand to diagnose and treat the most complex cases of Turkey, with great enthusiasm in general internal medicine and geriatrics.

"Cemil Taşcıoğlu" has been an epitome of excellence in clinician medicine. Full of modesty and curiosity, he was particularly keen in helping the patients whose diagnoses were rather enigmatic. Throughout Turkey, from east or west, it has been a custom, to transfer those patients failing to be diagnosed, to his examination. The "stepping stones" he used in the journey from symptoms to diagnosis provided him clarity and direction amidst the complicated diagnosis algorithm. Traces of vitality of a sound knowledge of semiology/symptomatology would be felt in professor's every discussion. Relentlessly accumulating his knowledge, Professor would always integrate new diseases, diagnostic and treatment methods into the classical wisdom and you would always be enriched by observing such amalgamation in his visits.

In his evaluations of the patients, impeccable physical examination was always accompanied by a probe into the patients' family structure, mental situation and social life. He did not perceive his patients as only corporal beings but as mental and social beings as well. Prominent with his clinician identity, he used to have a critical attitude towards laboratory medical practice. Perfection in his diagnoses was also a product of his life-long emphasis on communication

Address for Correspondence: Gülistan Bahat, Istanbul University, Istanbul Medical Faculty, Department of Internal Medicine, Division of Geriatrics, Istanbul, Turkey

Phone: +90 2124142000 E-mail: gbahatozturk@yahoo.com ORCID: orcid.org/0000-0001-5343-9795

Received: 26.05.2021 Accepted: 30.06.2021

Cite this article as: Bahat G. An Apple of Eye Legacy to the Humanity from Istanbul Medical Faculty: Professor Dr. Cemil Taşçığlu.

Eur J Geriatr Gerontol 2021;3(2):35-37

๑Copyright 2021 by the Academic Geriatrics Society / European Journal of Geriatrics and Gerontology published by Galenos Publishing House. 


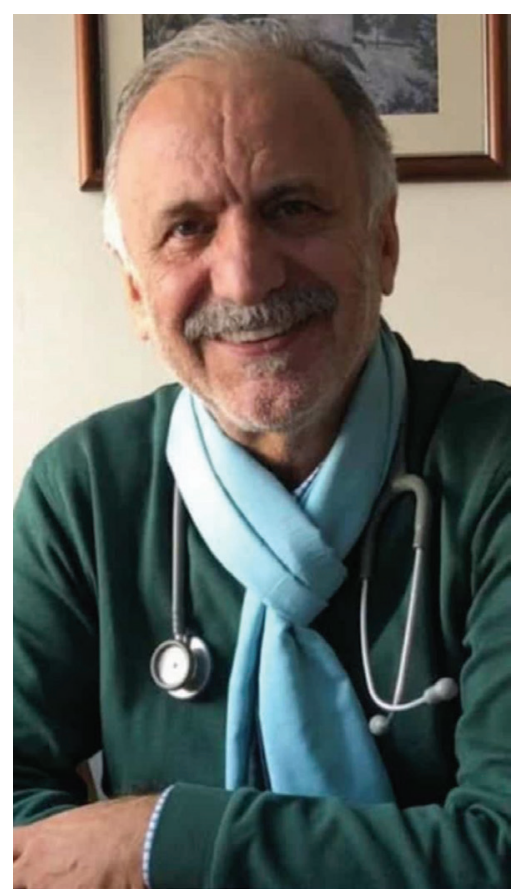

and collaboration as he always gave the verdict on diagnosis questions after intense consultations with his colleagues. He had a daily routine of selecting a patient with the most peculiar physical findings and studying her/him with his students. His students had such unique experience of diagnosing the hardest cases, giving them a sense of how medical contentedness could result from original thinking, cleverness and embracing complexity.

Professor Taşçıŏlu would transform his students and fellows into individuals with confidence and bright ideas, giving them full voice. We know that his happiest moments were when a controversial case presented itself and his students or assistants could point out the differential diagnosis before himself. Such precedents' validity did not matter to him; he was happy to see confident, intelligent beings who could give a judgment in a timely manner. Whenever such a judgment turned out to be true, he would always name its owner in all his visits, honoring hard work and complex thinking. He valued esteem and confidence; he very well knew that the students needed guidance in overcoming their social problems as well. And this he did not spare; he used all his power to support future generations' well-being and intellectual prowess.

He was a truly great instructor and professor. He treated his students and assistants as brothers/sisters and sons/daughters. He did not refrain from sharing his sincere feelings, creating ease and joy around himself. It was a routine for him to emanate artistic and humane messages every single day before starting his daily visits. He would repeat that "life was not long enough to postpone your ordained actions" and that one should not "put his/her dreams off." This motto was also a summary of his life style as he was always busy and energetic. Full of spirit, he would always smile and express himself strenuously, again a reflection of a mind that worked with speed. We have not witnessed any moment of aggression; if there is one thing he did not tolerate, it was languidness and lack of confidence.

Professor Taşçıoğlu's girth and joviality were reflected in his majestic medical and educational practice. Alive or inanimate, everything created was a target of his keen gaze and expression of love. Not only his students, assistants, colleagues but also animals, flowers, art -all that is part of the nature and culture- were dearest to him. His unstinting cordialness to the patients was so ample to attract jealousy of us, his colleagues. Humane exchanges of a few minutes on art, sports, cinema and painting preceding the visits would brighten our days and remind that medical excellence did not have the luxury to exclude intellectual fulfillment in various areas of arts and sciences. Art without science, and vice versa, was unthinkable to him. He would dress exquisitely with vivid colors, wrapping his foulard.

Professor Cemil Taş̧̧ığlu will always be alive in our memories. His marvel will live with us and future generations, his jollainess and colorful foulards will accompany in our minds his teachings. He taught us to think, speak up, heal and most importantly, to love our patients and each other.

He is a legendary clinician physician and one of the most beloved value of Istanbul Medical Faculty. He was actively working and sadly lost at Coronavirus disease-2019 pandemic in Turkey as the very first physician and health care worker on April 1, 2020 despite great efforts that has been put by his colleagues that love him by heart.

His loss overwhelmed his colleagues, his students, his patients and his lovers in the way that we have not experienced before. We revere the memory of his life of great teaching and clinical wisdom in medicine. We would kindly like to express our gratitudes and thanks to Professor Cemil Taşçığlu because meeting, studying, living with him and learning from him was an exceptional honour. He will be missed too much as an exceptional friend, an exceptional clinician and an exceptional teacher.

Both to honour his great legacy and to contribute to his immortality, a newly built, modern and high-capacity hospital was named after Professor Taş̧̧ığlu. Each medical facility and the individuals within will surely be effectively at the service of the patients who the Professor approached not as professional subjects but as friends. His colleagues -as his spirit will always be alive- will be inspired every time they hear the professor's name referred to. From now on, he has remained as an invaluable, apple of eye legacy to us, to Turkey, and to the humanity, believing sincerely that he has begun a new journey in the beauties already deserved by him. 
Keywords: COVID-19, internal medicine, mentor, obituary, Prof. Tascioglu

\section{Acknowledgement}

I would like to express my gratitutes to Mustafa Altınkaynak, MD; Timur Akpınar, Assoc. Prof; Mehmet Akif Karan, Prof; Nilgün Erten, Prof; Bulent Saka, Prof which is the team that have the honour of working with Prof. Cemil Taşçığlu for review of this article and for their hard effort during the illness of him.

\section{Ethics}

Peer-review: Internally peer-reviewed.

Financial Disclosure: The author declared that this study received no financial support. 